\title{
Pengaruh Corporate Governance, Profitability, Dan Foreign Ownership Terhadap Dividend Policy Pada Perusahaan Manufaktur Yang Terdaftar Di Bursa Efek Indonesia Periode 2014-2016
}

\author{
Nurainun Bangun, Yuniarwati dan Linda Santioso \\ Fakultas Ekonomi Universitas Tarumanagara Jakarta \\ Email:Inun66@yahoo.com,Email:Yuniarwati@fe.untar.ac.id Dan Email: \\ linda.santioso@gmail.com
}

\begin{abstract}
The purpose of this research is to analyze the effect of corporate governance, profitability, and foreign ownership on dividend policy. This research uses manufacturing company listed in Indonesia Stock Exchange for the period 2014-2016 as the population. Using purposive sampling, 95 data are selected as samples. Data processing in this research uses software program IBM SPSS version 23. The result shows that board size have a significant effect on dividend policy. Board independence do not have a significant effect on dividend policy. CEO duality do not have a significant effect on dividend policy. Profitability have a significant effect on dividend policy. Foreign ownership have a significant effect on dividend policy.
\end{abstract}

Key words: board size, board independence, CEO duality, profitability, foreign ownership, dividend policy

\begin{abstract}
Abstrak: Tujuan penelitian ini adalah untuk menganalisis pengaruh tata kelola perusahaan, profitabilitas, dan kepemilikan asing terhadap kebijakan dividen. Penelitian ini menggunakan perusahaan manufaktur yang terdaftar di Bursa Efek Indonesia untuk periode 2014-2016 sebagai populasi. Dengan menggunakan purposive sampling, 95 data dipilih sebagai sampel. Pengolahan data dalam penelitian ini menggunakan program perangkat lunak IBM SPSS versi 23. Hasilnya menunjukkan bahwa ukuran dewan memiliki pengaruh yang signifikan terhadap kebijakan dividen. Independensi dewan tidak memiliki pengaruh yang signifikan terhadap kebijakan dividen. Dualitas CEO tidak memiliki pengaruh signifikan terhadap kebijakan dividen. Profitabilitas memiliki pengaruh yang signifikan terhadap kebijakan dividen. Kepemilikan asing memiliki pengaruh yang signifikan terhadap kebijakan dividen.
\end{abstract}

Kata kunci: ukuran dewan, independensi dewan, dualitas CEO, profitabilitas, kepemilikan asing, kebijakan dividen

\section{PENDAHULUAN}

Perusahaan merupakan salah satu faktor penunjang ekonomi di suatu negara. Untuk dapat terus menjalankan kegiatan operasionalnya secara berkelanjutan, suatu perusahaan tentu membutuhkan sumber modal baik yang berasal pihak internal maupun eksternal. Sumber modal yang berasal dari pihak internal merupakan modal yang berasal dari dalam perusahaan itu sendiri. Sedangkan sumber modal yang berasal dari pihak eksternal merupakan sumber modal yang berasal dari luar perusahaan. 
Salah satu sumber modal eksternal dalam suatu perusahaan berasal dari investasi para investor. Oleh sebab itu, perusahaan harus berlaku adil terhadap investor perusahaan. Salah satu bentuk keadilan yang dapat diberikan perusahaan terhadap investor adalah melalui kebijakan dividen.

Penentuan kebijakan dividen seringkali menjadi permasalahan di dalam suatu perusahaan. Kebijakan dividen merupakan keputusan sulit yang harus diambil oleh pihak manajemen perusahaan untuk dapat mengalokasikan laba yang telah didapatkan. Pembagian dividen akan memenuhi harapan tingkat pengembalian bagi para investor. (Oktaviani dan Basana, 2015)

Penentuan kebijakan dividen dalam suatu perusahaan ditentukan oleh beberapa faktor, antara lain corporate governance yang terdiri dari board size, board independence, dan CEO duality, profitability dalam suatu perusahaan, serta adanya kepemilikan asing dalam suatu perusahaan (foreign ownership). Oleh karena permasalahan yang telah diuraikan di atas, maka penelitian ini dilakukan dengan tujuan untuk membuktikan secara empirispengaruh board size, board independence, CEO duality, profitability, dan foreign ownership terhadap kebijakan dividen.

\section{KAJIAN TEORI}

Teori Agensi. Teori agensi merupakan teori yang mengatur hubungan antara pemegang saham dengan manajer perusahaan. Hubungan keagenan terjadi saat pihak pemegang saham memberikan wewenang kepada pihak manajer perusahaan untuk mengambil sebuah keputusan. Namun, tidak selalu keputusan yang diambil oleh manajer perusahaan mencerminkan kepentingan para pemegang saham. Hal ini kemudian akan menimbulkan agency conflict.

Agency conflict dapat terjadi ketika manajer perusahaan mengambil suatu tindakan yang lebih mencerminkan preferensi manajer. Tindakan yang diambil oleh manajer ini akan bertentangan dengan kepentingan pemegang saham, yaitu mendapatkan tingkat pengembalian yang tinggi dari investasi yang telah dilakukan. (Jensen dan Meckling, 1976)

Dividend Policy. Secara umum, seorang manajer yang ada dalam suatu perusahaan harus mampu mengatur aktivitas pendanaan yang ada dalam perusahaan. Bagaimana perusahaan mampu memperoleh serta mengalokasikan dana yang dimiliki dengan baik. Salah satu cara yang digunakan manajer perusahaan dalam mengelola pendanaan yang dimiliki suatu perusahaan adalah dengan kebijakan dividen.

Kebijakan dividen merupakan salah satu aspek penting yang harus ada di dalam suatu perusahaan.Kebijakan dividen digunakan untuk membantu perusahaan dalam aktivitas pengambilan keputusan pendanaan perusahaan. Sebuah perusahaan berperan dalam menentukan seberapa besar laba yang akan dibagikan kepada investor dan seberapa besar laba yang akan ditahan oleh perusahaan untuk menunjang kegiatan operasional perusahaan selanjutnya (Dewi dan Sedana, 2012).

Corporate Governance. Kulathunga et al. (2017) mendefinisikan corporate governance sebagai mekanisme, proses, dan hubungan dimana terdapat organisasi yang memantau dan mengarahkannya.Dalam penerapannya corporate governancemenggunakan board size, board independence dan CEO duality sebagai indikator dalam penelitian ini. 
Pengetahuan atas board size dalam suatu perusahaan merupakan hal yang penting karena board of directors mengambil peranan utama dalam merealisasikan corporate governance di perusahaan modern. Board independence diperlukan dalam suatu perusahaan untuk menjaga efektivitas mekanisme corporate governance. Sedangkan $C E O$ duality merupakan suatu kondisi dimana CEO juga menjabat sebagai pemimpin suatu dewan.

Profitability. Profitabilitas adalah kemampuan perusahaan memperoleh laba dalam hubungannya dengan penjualan, total aktiva maupun modal sendiri. Dengan demikian, investor jangka panjang akan sangat berkepentingan dengan analisis profitabilitas ini, misalnya pemegang saham akan melihat keuntungan yang benar - benar akan diterima dalam bentuk dividen (Sartono, 2012:122, dalam Nidya dan Farida, 2015). Profitabilitas menjadi mutlak diperlukan untuk perusahaan ketika perusahaan hendak membayar dividen.

Foreign Ownership. Pemodal asing merupakan perseorangan warga negara asing ataupun suatu badan hukum asing. Secara umum, kepemilikan asing dapat dilihat dengan adanya kepemilikan dari investor asing dari total saham perusahaan (Jayanti dan Puspitasari, 2017). Berkaet dan Harvey (2000) dalam Lucyanda dan Lilyana (2012) menyatakan bahwa adanya kepemilikan asing dalam suatu perusahaan diharapkan dapat meningkatkan kinerja perusahaan karena kepemilikan asing tersebut akan memberikan tekanan tertentu bagi perusahaan untuk meningkatkan laba yang dihasilkan.

Hipotesis. Hipotesis yang digunakan dalam melakukan penelitian ini merupakan pernyataan singkat yang disimpulkan dari tinjauan pustaka dan merupakan uraian sementara dari permasalahan yang ada. Hipotesis akan diterima jika hasil analisis dan empiris membuktikan bahwa hipotesis tersebut benar, begitu pula sebaliknya.

H1 : Board size berpengaruh positif dan signifikan terhadap dividend policy.

$\mathrm{H} 2$ : Board independence berpengaruh positif dan signifikan terhadap dividend policy.

H3 : CEO duality berpengaruh negatif dan signifikan terhadap dividend policy.

H4 : Profitability berpengaruh positif dan signifikan terhadap dividend policy.

H5 : Foreign ownership berpengaruh positif dan signifikan terhadap dividend policy.

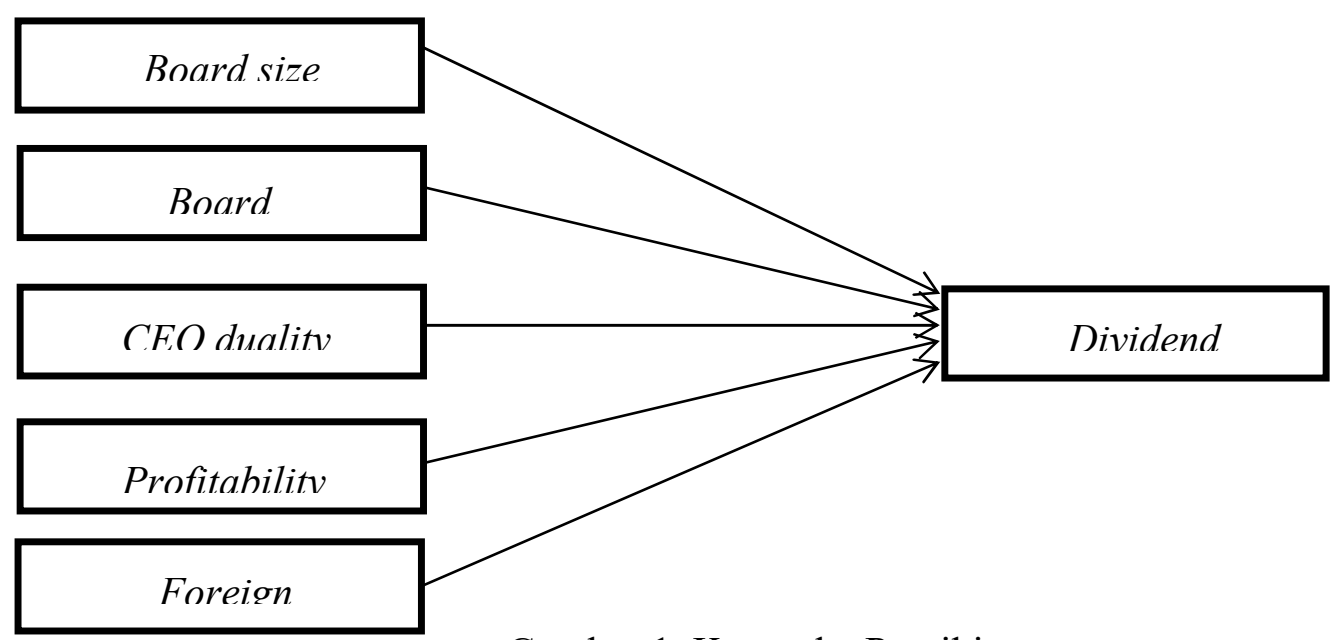

Gambar 1. Kerangka Pemikiran 


\section{METODE}

Populasi, Teknik Pemilihan Sampel, dan Ukuran Sampel. Populasi dalam sampel ini adalah perusahaan manufaktur yang terdaftar di Bursa Efek Indonesia (BEI) periode 20142016.Pemilihan sampel menggunakan purposive sampling yaitu teknik sampling yang digunakan peneliti jika peneliti mempunyai pertimbangan tertentu didalam pengambilan sampelnya atau penentuan sampel dengan kriteria tertentu.Kriteria- kriteria tersebut adalah sebagai berikut:(1) Perusahaan manufaktur yang sudah terdaftar di Bursa Efek Indonesia (BEI) periode 2014-2016. (2) Perusahaan manufaktur yang menerbitkan laporan keuangannya secara lengkap dan telah diaudit per 31 Desember selama tahun 2014-2016. (3) Perusahaan manufaktur yang dalam laporan keuangannya menggunakan mata uang Rupiah. (4) Perusahaan manufaktur yang tidak mengalami kerugian selama tahun 20142016. (5) Perusahaan manufaktur yang membayar dividen kas secara konsisten atau berturut-turut selama periode penelitian dari tahun 2014-2016.

Dari kriteria tersebut terdapat 39 perusahaan yang memenuhi kriteria untuk dijadikan sebagai sampel dan dalam 39 perusahaan tersebut terdapat data yang sangat berbeda jauh dengan data lainnya sehingga data perusahaan tersebut harus dibuang / outlier. Dari hasil uji outlier, total sampel dari periode 2014-2016 hanya terdapat 95 sampel.

\section{Operasionalisasi Variabel dan Instrumen}

1. Variabel Dependen. Variabel dependen merupakan variabel yang dipengaruhi oleh variabel independen.Variabel dependen yang digunakan dalam penelitian ini yaitu dividend policy.Dividend policy merupakan kebijakan yang ditentukan oleh perusahaan untuk membagikan dividen kepada para pemegang saham perusahaan. (Anuar et al., 2014)

Dividend policy dapat dihitung dengan:

$$
\text { Dividend policy }=\frac{\text { Dividen }}{\text { Net income after tax }}
$$

2. Variabel Independen. Variabel independen merupakan variabel yang mempengaruhi variabel dependen. Variabel independen yang digunakan dalam penelitian ini yaitu board size, board independence, CEO duality, profitability, dan foreign ownership.

a) Board Size. Board size merupakan jumlah dewan direksi yang terdapat di dalam perusahaan. (Kulathunga et al., 2017)

Board size dapat dihitung dengan:

Board size $=$ Jumlah dewan direksi dalam perusahaan

b) Board Independence. Pengukuran board independence dilakukan dengan cara membandingkan jumlah dewan komisaris independen dengan total dewan komisaris yang terdapat di dalam perusahaan. (Mai, 2014)

Board independencedapat dihitung dengan:

$$
\text { Board independence }=\frac{\text { Jumlah dewan komisaris independence }}{\text { Total dewan komisaris }}
$$

c) $C E O$ duality. Pengukuran $C E O$ duality dilakukan dengan cara variabel dummy. Peneliti akan menggunakan ' 1 ' untuk perusahaan yang memiliki CEOduality dan '0' untuk perusahaan yang tidak memiliki $C E O$ duality.(Kulathunga et al., 2017). 
d) Profibtability. Profitability dilakukan untuk mengukur pendapatan atau keberhasilan operasi suatu perusahaan dalam jangka waktu tertentu. Perhitungan profitability yang dilakukan dalam penelitian ini adalah menggunakan Return On Assets (ROA). (Fatemian dan Hooshyarzadeh, 2016)

$$
\text { Return on Assets }=\frac{\text { Net Income before tax }}{\text { Total Assets }}
$$

e) Foreign Ownership. Foreign ownership dilakukan untuk melihat apakah terdapat kepemilikan asing di dalam suatu perusahaan.Pengukuran foreign ownership dilakukan dengan variabel dummy, dimana ' 1 ' digunakan apabila tedapat foreign ownership dalam perusahaan, dan ' 0 ' apabila tidak terdapat foreign ownership dalam perusahaan. (Jayanti dan Puspitasari, 2017)

\section{HASIL DAN PEMBAHASAN}

Hasil Uji Statistik Deskriptif. Dalam melakukan uji statistik deskriptif, dapat memberikan gambaran mengenai mean, standar deviasi, minimum dan maksimum data yang digunakan dalam melakukan penelitian. Berikut merupakan hasil uji statistik deskriptif menggunakan SPSS 23:

Tabel 1. Hasil Uji Statistik Deskriptif

Descriptive Statistics

\begin{tabular}{lccccc}
\hline & $\mathrm{N}$ & Minimum & Maximum & Mean & Std. Deviation \\
\hline DIVIDEND POLICY & 95 &, 056 &, 975 &, 36898 &, 210572 \\
BOARD SIZE & 95 & 3,000 & 13,000 & 6,05263 & 2,335519 \\
BOARD & 95 &, 286 &, 600 &, 38550 &, 071831 \\
INDEPENDENCE & 95 &, 000 & 1,000 &, 01053 &, 102598 \\
CEO DUALITY & 95 &, 015 &, 383 &, 12616 &, 077379 \\
PROFITABILITY & 95 &, 000 & 1,000 &, 80000 &, 402122 \\
FOREIGN OWNERSHIP & 95 & & & & \\
Valid N (listwise) & 95 & & & & \\
\hline
\end{tabular}

Berdasarkan hasil uji statistik deskriptif yang telah dilakukan menunjukkan bahwa variabel dependen yaitu dividend policy memiliki nilai minimum sebesar 0,056, nilai maksimum sebesar 0,975 dan nilai mean sebesar 0,36898. Variabel board sizememiliki nilai minimum sebesar 3, nilai maksimum sebesar 13 dan nilai mean sebesar 6,05263. Variabel board independence menunjukkan nilai minimum sebesar 0,286, nilai maksimum sebesar 0,6 dan memiliki nilai meansebesar 0,38550. Variabel CEO dualitymemiliki nilai minimum sebesar 0 , nilai maksimum sebesar 1 dan nilai meansebesar 0,01053 . Variabel profitabilitymemiliki nilai minimum sebesar 0,015, nilai maksimum sebesar 0,383 dan nilai meansebesar 0,12616. Variabel foreign ownership memiliki nilai minimum sebesar 0 , nilai maksimum sebesar 1 dan nilai mean sebesar 0,8 .

Hasil pengujian Asumsi Klasik. Uji Normalitas. Selanjutnya, untuk melakukan pengujian hipotesis, sebelumnya harus melakukan pengujian normalitas dan uji asumsi 
klasik pada model regresi.Dalam melakukan uji normalitas, penelitian ini menggunakan One-Sample Kolmogorov-Smirnov Test. Hasil uji tersebut menunjukkan bahwa Unstandardized Residual nilai Asymp.Sig. (2-tailed) sebesar 0,200.Hal ini menunjukkan bahwa nilai Asymp. Sig. (2-tailed) memiliki nilai yang lebih besar dari 0,05. Dengan demikian, model regresi yang digunakan telah terdistribusi secara normal dan telah memenuhi syarat uji normalitas sehingga dapat melanjutkan pengujian multikolinearitas.

Uji Multikolinearitas. Dalam melakukan uji multikolinearitas, hasilnya menunjukkan bahwa variabel board size, board independence, CEO duality, profitability dan foreign ownershipmasing-masing memiliki nilai tolerance sebesar $0,971,0,799,0,973,0,968$ dan 0,794 serta masing-masing memiliki nilai $V I F$ sebesar 1,030, 1,251, 1,028, 1,033 dan 1,260. Hal ini dapat disimpulkan bahwa semua variabel independen dalam penelitian ini memiliki nilai tolerance yang lebih besar dari 0,1 dan nilai VIF yang lebih kecil dari 10 . Dengan demikian, model regresi yang digunakan terbebas dari multikolinearitas.

Uji Autokorelasi. Selanjutnya penelitian melakukan uji autokorelasi. Hasil uji autokorelasi menunjukkan bahwa nilai Durbin-Watson sebesar 1,890. Nilai DurbinWatson 1,890 terletak diantara 1,7781 sampai dengan 2,2219. Hasil dari model regresi yang digunakan dalam penelitian ini menunjukkan bahwa tidak terjadi autokorelasi dengan tingkat kepercayaan $95 \%$.

Uji Heteroskedastisitas. Uji asumsi klasik yang terakhir adalah uji heteroskedastisitas. Hasil uji heteroskedastisitas menunjukkan bahwa variabel board size, board independence, CEO duality, profitability dan foreign ownership masing-masing menunjukkan nilai sebesar $0,730,0,883,0,186,0,545$ dan 0,111 . Hal ini menunjukkan bahwa model regresi yang digunakan tidak mengandung heteroskedastisitas dikarenakan memiliki nilai signifikansi yang lebih besar dari 0,05 .

Persamaan Regresi Linear Berganda. Pengujian normalitas dan asumsi klasik telah dilakukan maka berdasarkan hasil pengujian tersebut, peneliti akan mencoba memberikan inti temuan penelitian secara keseluruhan. Berikut merupakan hasil analisis regresi linear berganda:

$$
D P=0,371+0,020 B S-0,310 B I-0,030 C D+0,744 P B-0,121 F O
$$

Persamaan regresi tersebut dapat diartikan sebagai berikut:

Konstanta (a): 0,371 yang dapat diartikan bahwa apabila $B S, B I, C D, P B$ dan $F O$ sama dengan nol, maka $D P$ akan memiliki nilai sebesar 0,371 .

Koefisien regresi Board Size (BS) memiliki nilai sebesar 0,020. Hal ini dapat diartikan bahwa jika variabel independen lainnya sama dengan nol dan BS mengalami kenaikan 1 satuan maka Dividend Policy (DP) akan mengalami kenaikan sebesar 0,020. Hal ini dikarenakan $B S$ dan $D P$ memiliki hubungan yang positif, semakin besar $B S$ maka akan semakin besar juga $D P$.

Koefisien regresi Board Indepedence (BI) memiliki nilai sebesar -0,310. Hal ini dapat diartikan bahwa jika variabel independen lainnya sama dengan nol dan $B I$ mengalami kenaikan 1 satuan, maka Dividend Policy (DP) akan mengalami penurunan 
sebesar 0,310 . Hal ini dikarenakan $B I$ dan $D P$ memiliki hubungan yang negatif, semakin sebesar $B I$ maka akan semakin kecil $D P$.

Koefisien regresi $C E O$ duality $(C D)$ memiliki nilai sebesar $-0,030$. Hal ini menunjukkan bahwa jika variabel independen lainnya sama dengan nol dan CD mengalami kenaikan 1 satuan, maka Dividend Policy (DP) akan mengalami penurunan sebesar 0,030. Hal ini dikarenakan $C D$ dan $D P$ memiliki hubungan yang negatif, semakin besar $C D$ maka akan semakin kecil $D P$.

Koefisien regresi Profitability (PB)memiliki nilai sebesar 0,744. Hal ini dapat diartikan bahwa jika variabel independen lainnya memiliki nilai yang sama dengan nol dan PB mengalami kenaikan 1 satuan, maka nilai Dividend Policy (DP) akan mengalami kenaikan sebesar 0,744 . Hal ini dikarenakan $P B$ dan $D P$ memiliki hubungan yang positif, semakin besar $P B$, maka semakin besar $D P$.

Koefisien regresi Foreign Ownerhsip (FO) memiliki nilai sebesar -0,121. Hal ini dapat diartikan jika variabel independen lainnya memiliki nilai sama dengan nol dan FO mengalami kenaikan sebesar 1 satuan, maka Dividend Policy (DP) akan mengalami penurunan sebesar 0,121 . Hal ini dikareanakan $F O$ dan $D P$ memiliki hubungan yang negatif sehingga semakin besar $F O$ maka akan semakin kecil $D P$.

Pengujian Hipótesis. Uji Koefisien Determinasi (Adjusted $\boldsymbol{R}^{2}$ ). Dengan melakukan uji $\mathrm{R}^{2}$, diharapkan bisa mengukur seberapa besar kontribusi atau pengaruh yang diberikan variabel independen terhadap variabel dependen. Berikut merupakan hasil Uji $\mathrm{R}^{2}$ yang telah dilakukan:

Tabel 2. Hasil Uji Koefisien Determinasi

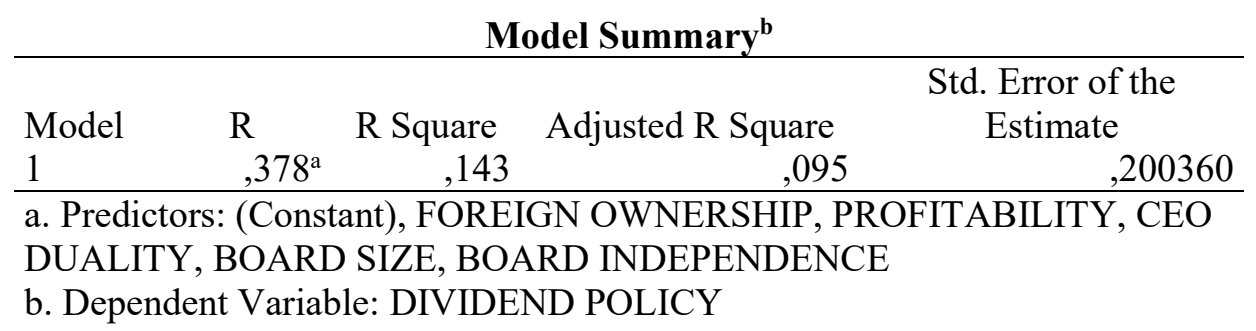

Berdasarkan hasil uji di atas, menunjukkan bahwa nilai Adjusted $R$ Square sebesar $9,5 \%$. Dengan demikian, variabel independen yang digunakan dalam penelitian dapat menjelaskan hanya sebesar 9,5\% saja terhadap variabel dependen dan untuk sisanya yang sebesar 90,5\% lebih dijelaskan oleh faktor-faktor lain di luar variabel independen yang digunakan dalam penelitian ini.

Uji F.Untuk mengetahui apakah model regresi yang digunakan layak atau tidak dan apakah terdapat pengaruh antar variabel independen terhadap variabel dependen secara simultan atau bersama-sama dapat diketahui dengan melakukan uji F. Berikut merupakan hasil uji F yang dilakukan dalam penelitian ini: 
Tabel 3. Hasil Uji F

\begin{tabular}{ccccccc}
\multicolumn{8}{c}{ ANOVA $^{\mathbf{a}}$} \\
\hline & Model & Sum of & & & & \\
& Squares & df & Mean Square & F & Sig. \\
\hline 1 & Regression &, 595 & 5 &, 119 & 2,965 &, $016^{\text {b }}$ \\
& Residual & 3,573 & 89 &, 040 & & \\
& Total & 4,168 & 94 & & & \\
\hline
\end{tabular}

a. Dependent Variable: DIVIDEND POLICY

b. Predictors: (Constant), FOREIGN OWNERSHIP, PROFITABILITY, CEO

DUALITY, BOARD SIZE, BOARD INDEPENDENCE

Berdasarkan hasil peneltian di atas, menunjukkan bahwa tingkat signifikansi sebesar 0,016. Hal ini dapat diartikan bahwa model regresi yang digunakan layak dan variabel independen yang digunakan dalam penelitian ini memiliki pengaruh terhadap variabel dependen secara bersama-sama atau simultan dikarenakan nilai signifikansinya lebih kecil dari pada 0,05 .

\section{Uji t}

Tabel 4. Hasil Uji t

Coefficients $^{\mathbf{a}}$

\begin{tabular}{|c|c|c|c|c|c|c|}
\hline \multirow{2}{*}{\multicolumn{2}{|c|}{ Model }} & \multicolumn{2}{|c|}{$\begin{array}{c}\text { Unstandardized } \\
\text { Coefficients }\end{array}$} & \multirow{2}{*}{$\begin{array}{c}\text { Standardized } \\
\text { Coefficients } \\
\text { Beta }\end{array}$} & \multirow[b]{2}{*}{$\mathrm{t}$} & \multirow[b]{2}{*}{ Sig. } \\
\hline & & $\mathrm{B}$ & Std. Error & & & \\
\hline \multirow[t]{6}{*}{1} & (Constant) & ,371 & , 159 & & 2,334 & ,022 \\
\hline & BOARD SIZE & , 020 & , 009 & 220 & 2,208 & ,030 \\
\hline & $\begin{array}{l}\text { BOARD } \\
\text { INDEPENDENCE }\end{array}$ &,- 310 & ,322 &,- 106 &,- 962 & ,339 \\
\hline & CEO DUALITY &,- 030 & ,204 &,- 015 &,- 149 & ,882 \\
\hline & ROA & ,744 & ,271 & ,273 & 2,741 & ,007 \\
\hline & $\begin{array}{l}\text { FOREIGN } \\
\text { OWNERSHIP }\end{array}$ &,- 121 & ,058 &,- 231 & $-2,092$ & ,039 \\
\hline
\end{tabular}

a. Dependent Variable: DIVIDEND POLICY

Berdasarkan hasil uji t diatas, variabel board size memiliki nilai signifikansi sebesar 0,030 yaitu lebih kecil dari 0,05. Hal tersebut menunjukkan bahwa variabel board size memiliki pengaruh yang positif dan signifikan terhadap dividend policy. Dengan demikian dapat disimpulkan bahwa hipotesis pertama diterima. Dengan adanya board size yang tepat, perusahaan dapat melakukan koordinasi dengan lebih baik dan efektif sehingga akan mengurangi masalah komunikasi dalam perusahaan tersebut. Hal ini akan berdampak pada kemampuan perusahaan dalam mengatasi agency conflict dan akan berdampak pula pada penentuan kebijakan dividen. Hasil penelitian ini sejalan dengan penelitian yang dilakukan oleh Mansourinia et al. (2013) yang mengatakan bahwa variabel board size memiliki pengaruh yang signifikan terhadap dividend policy.

Variabel board independence memiliki nilai signifikansi sebesar 0,339 yaitu lebih besar dari 0,05. Hal tersebut menunjukkan bahwa variabel board independence tidak memiliki pengaruh yang signifikan terhadap dividend policy. Dengan demikian dapat disimpulkan bahwa hipotesis kedua ditolak. Jumlah komisaris independen yang ada dalam 
suatu perusahaan cenderung lebih sedikit dibandingkan dengan komisaris perusahaan sehingga hak suara yang dimiliki oleh komisaris independen tidak memiliki pengaruh yang signifikan terhadap pengambilan kebijakan oleh perusahaan. Hasil penelitian ini sejalan dengan penelitian yang dilakukan oleh Ajanthan (2013) yang mengatakan bahwa variabel board independence tidak memiliki pengaruh yang signifikan terhadap dividend policy.

Variabel CEO duality memiliki nilai signifikansi sebesar 0,882 yaitu lebih besar dari 005. Hal tersebut menunjukkan bahwa variabel $C E O$ duality tidak memiliki pengaruh yang signifikan terhadap dividend policy. Dengan demikian dapat disimpulkan bahwa hipotesis ketiga ditolak. Keberadaan CEO duality di dalam suatu perusahaan tidak memberikan dampak yang signifikan terhadap pengambilan kebijakan perusahaan selama dewan yang menjabat memiliki integritas dan sikap profesional yang baik sehingga kebijakan tetap dapat ditetapkan secara efektif dan efisien. Hasil penelitian ini sejalan dengan penelitian yang dilakukan oleh Mansourinia et al. (2013) yang mengatakan bahwa variabel $C E O$ duality tidak memiliki pengaruh yang signifikan terhadap dividend policy.

Variabel profitability memiliki nilai signifikansi sebesar 0,007 yaitu lebih kecil dari 0,05 . Hal tersebut menunjukkan bahwa variabel profitability memiliki pengaruh positif yang signifikan terhadap dividend policy. Dengan demikian dapat disimpulkan bahwa hipotesis keempat diterima. Dengan adanya tingkat profitabilitas yang tinggi dalam suatu perusahaan, investor akan cenderung lebih percaya terhadap perusahaan tersebut dalam menginvestasikan uangnya. Dengan modal yang tinggi, perusahaan juga dapat melakukan kegiatan operasional yang lebih optimal sehingga laba yang dihasilkan lebih tinggi. Dengan laba yang tinggi, penetapan dividend policy di dalam perusahaan juga akan terpengaruh. Hasil penelitian ini sejalan dengan penelitian yang dilakukan oleh Fatemian dan Hooshyarzadeh (2016) yang mengatakan bahwa variabel profitability memiliki pengaruh yang signifikan terhadap dividend policy.

Variabel foreign ownership memiliki nilai signifikansi sebesar 0,039 yaitu lebih kecil dari 0,05 . Hal tersebut menunjukkan variabel foreign ownership memiliki pengaruh yang signifikan terhadap dividend policy, tetapi arah yang diperoleh adalah negatif. Dengan demikian dapat disimpulkan bahwa hipotesis kelima ditolak. Pemodal asing di suatu perusahaan cenderung menuntut perusahaan untuk menggunakan laba yang dihasilkan untuk kegiatan operasional perusahaan di masa yang akan datang sehingga kegiatan operasional dapat dilakukan dengan lebih efektif dan efisien dan laba yang dihasilkan di masa yang akan datang juga lebih optimal.

\section{PENUTUP}

Berdasarkan hasil penelitian yang dilakukan, maka dapat disimpulkan bahwa variabel board size, profitability, dan foreign ownership memiliki pengaruh yang signifikan terhadap dividend policy. Board independence dan $C E O$ duality tidak memiliki pengaruh yang signifikan terhadap dividend policy.

Penelitian ini memiliki beberapa keterbatasan yaitu hanya menggunakan sektor manufaktur saja dan periode penelitian yang digunakan hanya tahun 2014-2016. Selain itu variabel yang digunakan hanya terbatas pada board size, board independence, CEO duality, profitability dan foreign ownership. 
Berikut beberapa saran yang dapat dijadikan masukan bagi para peneliti selanjutnya yaitu untuk penelitian selanjutnya diharapkan dapat memperluas sampel penelitian tidak hanya pada sektor manufaktur saja, dan juga memperpanjang periode penelitian. Selain itu juga diharapkan dapat menambah variabel lainnya sebagai faktor yang mempengaruhi dividend policy pada perusahaan.

\section{DAFTAR RUJUKAN}

Ajanthan, A. (2013). "Corporate Governance and Dividend Policy: A Study of Listed Hotels and Restaurant Companies in Sri Langka". International Journal of Management, IT and Engineering (IJMIE, 3(12), 98-114.

Anuar, N. L. M., Yakob, N. A., \& Jr, C. B. M. (2014). "The Impact of Profitability, Liquidity, Leverage, and Firm Size on Cash Dividend Payments for Public Listed Companies in Malaysia and Thailand". The Global Journal of Finance and Economics, 11(2), 101-129.

Dewi, N. W. T., \& Sedana, I. B. P. (2012). "Pengaruh Struktur Modal, Likuiditas, dan Pertumbuhan terhadap Kebijakan Dividen di BEI". Jurnal Manajemen Unud, 17391752.

Fatemian, F. \& Mohammad, H. (2016). "Role of Dividend Policy Determinants in Multinational and Domestic Companies, Evidence from Iran". Problems and Perspectives in Management, 14(3), 332-340.

Jayanti, I. S. D., \& Puspitasari, A. F. P. (2017). "Struktur Kepemilikan dan Kebijakan Dividen pada Perusahaan Manufaktur di Indonesia". The Indonesian Journal of Applied Business, 1(1), 1-13.

Jensen, M. C., \& Meckling, W. H. (1976). Theory of the Firm: Managerial Behavior, Agency Costs and Ownership Structure.Journal of Financial Economics, 3(4), 305360.

Kulathunga, K.M.K.N.S., Weerasinghe, W.D.J.D., Jayarathne, J.A.B. (2017). “Corporate Governance and Dividend Policy: A Study of Listed Manufacturing Companies in Sri Langka". International Journal of Scientific Research and Innovative Technology, 4(2), 64-81.

Lucyanda, J., \& Lilyana. (2012). "Pengaruh Free Cash Flow dan Struktur Kepemilikan terhadap Dividend Payout Ratio". Jurnal Dinamika Akuntansi, 4(2), 129-138.

Mai, M. U. (2015). "Pengaruh Corporate Governance Mechanism Terhadap Nilai Perusahaan Melalui Pertumbuhan, Profitabilitas, dan Kebijakan Dividen". Jurnal Ekonomi dan Keuangan, 19(1), 42-65.

Mansourinia, E., Emamgholipur, M., Rekabdarkolaei, E.A. \& Hozoori, M. (2013). “The Effect of Board Size, Board Independence and CEO Duality on dividend Policy of Companies: Evidence from Tehran Stock Exchange". International Journal of Economy, Management and Social Sciences, 2(6), 237-241.

Nidya, A.P. \& Farida.(2015). "Pengaruh Debt to Equity Ratio, Profitabilitas, Growth, dan Ukuran Perusahaan Terhadap Kebijakan Dividen". e-Proceeding of Management, 2(1), 488-496.

Oktaviani, L., \& Basana, S. R. (2015). "Analisis Faktor-Faktor yang Mempengaruhi Kebijakan Dividen". Journal of Research in Economics and Management, 15(2), 361-370. 